\title{
Tax Policy Impact on the Entrepreneurial Development in Latvia
}

\author{
Elza Sipola \\ Department of Economy, the Riga Aeronautical Institute, Mezkalnu str. 9, Riga LV-1058, Latvia
}

\begin{abstract}
According to the first National documents, it is obvious that before joining the EU, Latvian tax policy goals were to promote economic growth and investment providing a stable business environment and to provide of competitiveness in Latvia. Before joining the EU, one of the main aspects of the tax policies in Latvia was reducing the tax burden business in order to promote sustainable development and economic competitiveness. Moreover, the emphasis was set on consumption rather than income tax, thus, contributing to capital accumulation and investment. It is important to take into account the business views because they are the core, which in the most tax deductions to the state budget. This study surveyed in 2013 and found out entrepreneurs' attitude of the government and tax policy on business processes. The paper came to the conclusion, that too heavy tax burden really interferes with new enterprises and business in general. The survey analyze provide real abidance, that modern tax policy in Latvia does not take into account the economic crisis impact on business. The tax policy plays the key role for Latvian business competitiveness. Therefore, it is convinced that the existing tax policy has to be revised by relevant authorities.
\end{abstract}

Key words: Taxation, entrepreneurship, development, survey.

\section{Introduction}

Tax and fee system of the Republic of Latvia is regulated by the Law "On Taxes and Fees", and is considered to be the main legislation act for the tax system [1].

It states the general tax and fee system's applying principles as well as the types of taxes and fees, tax and fee assessment method, taxpayers' rights, obligations and responsibilities; taxpayer registration procedure, tax administration rights, duties and responsibilities, collection and recovery of tax and fees, liability for violation of the tax laws, dispute and appeal procedures relating the decisions taken on the taxes and fees [2,3].

The goal of the paper was to find out the opinions of the entrepreneurs and potential entrepreneurs about tax policy impact on the entrepreneurial development in Latvia, which would be the basis for the conclusions and new recommendations. The paper conducted a survey of entrepreneurs in 2013-2014.

Correnceponding author: Elza Sipola, master, research field: tax policy. E-mail: elza.sipola@inbox.lv.
The opinions of the entrepreneurs are important, as the entrepreneurship is the core of the country that provides the highest tax contributions to the state and local authority budgets.

\section{Materials}

Taking into account the fact that in the course of the entrepreneurial development it is often proved that the company's success depends not only on the company's own performance in a relevant sector or market segment, but also on various external factors, the factors affecting the company's operations should be studied and assessed. There are factors that can be predicted and affected, but there are also those factors that cannot be affected by the company and cannot be avoided.

In order to get as many respondents as possible, the electronic selection of respondents has been adopted, which corresponds to the characteristics of the target audience of the study: professionals of different types and sizes of business who are located in different Latvian regions as well as the final-year students, who 
are studying entrepreneurship in the higher education institutions (RPIVA, RAI, RISEBA). The simple random selection of respondents has been carried out according to their regions and e-mail addresses posted on the website. All respondents were guaranteed anonymity. The survey was conducted in the winter of 2013/2014, and 156 responses were received [4]

According to the author's opinion, taxes should not be a burden for entrepreneurs, since the too high tax rate may slow down the business development of any company as well as the general economic development of the country.

By exploring some of the documents adopted at the national level, one can clearly see that the objectives of the Latvian tax policy are the followings [5]:

- to promote economic growth and attraction of the investments, thus providing a stable business environment;

- to ensure the competitiveness of the country.

The following main tasks of the tax policy have been set in order to ensure the achievement of the policy objectives [6]:

- to create a fair and neutral tax system which would be easy to be regulated;

- to improve tax administration and improve the collection of tax arrears;

- to ensure collection of tax return which is included in the budget.

According to the subparagraph 3.1.1 (Tax Policy) of the "EU Pre-accession Economic Programme" [3], one of the main directions of the tax policy in Latvia before joining the EU was the reduction of the tax burden in the entrepreneurship in order to promote sustainable development and economic competitiveness. In addition, the primary focus was on the consumption taxation rather than income taxation, thus promoting the capital accumulation and investment attraction [7].

The results of the survey provide the following attitude of the entrepreneurs (or potential entrepreneurs) to the current government and tax policy impact on business processes.

\section{Results and Discussion}

According to the answers of the respondents, their level of education has been identified (Fig. 1) [4].

The largest part of the respondents had an incomplete higher education $-38.5 \%$ of all the respondents and the next largest group had a Bachelor's degree $-33.3 \%$ of all the respondents. This indicates that the students were more responsive than the entrepreneurs who are not related to the learning process.

The different level of the respondents' education provides an author the larger opportunity to learn the nature of the problem and different views depending on the level of education.

It was significant for the author to identify the breakdown of the respondents by the professional categories in entrepreneurship, so the following question has been asked: "Which professional category is the best for you at the moment?" The collected responses can be viewed in Fig. 2.

Among the respondents, $22.4 \%$ of all the respondents

\begin{tabular}{|l|l|l|}
\hline Secondary education & & $12.8 \%$ \\
\hline Incomplete higher education & & $38.5 \%$ \\
\hline Bachelor's degree & & $33.3 \%$ \\
\hline Master's degree or higher & & $15.4 \%$ \\
\hline
\end{tabular}

Fig. 1 Summarization of the results of the respondents by the education level. 


\begin{tabular}{|l|l|}
\hline Potential entrepreneur - person who is planning to start the \\
own business within three years.
\end{tabular}

Fig. 2 Summarization of the results of the respondents by the professional category.

were persons who have an intention to start their own business within three years (potential entrepreneurs); $14.7 \%$ of all the respondents-nascent entrepreneurs, persons who are actively trying to start a new business; $7.7 \%$ of all the respondents were the owners of the start-up companies-persons who run a business and are full or partial owners of the company and who have paid wages; $7.7 \%$ of all the respondents were persons managing and owning a company (owners of the mature companies); business professionals of different levels who do not own a company comprised $47.5 \%$ of all the respondents.

According to the results of the survey, this group of respondents who do not own a company was the largest of all the groups.

In the author's opinion, a more detailed breakdown of the respondents by professional categories in the entrepreneurship will provide a larger opportunity to identify the nature of the problem and the different views on the problem. As it could be concluded from the data of the Fig. 2, the respondents represented all professional categories in the entrepreneurship: current and potential managers of the companies, company owners, business professionals and entrepreneurs of different levels.

It was significant for the author to find out the thoughts of the entrepreneurs whether it is real to start a new business in Latvia taking into account the state and government policy, including the tax policy. The respondents were asked the following question: "How do you assess the opportunity to start a new business in Latvia?"

According to the experiences and the responses, only $25 \%$ of the respondents from all respondents noted that it is difficult to start business in Latvia, but $70 \%$ of respondents from all respondents answered that it is easy to start business in Latvia.

Tax burden has a direct impact on business. The higher taxes have to pay the company, the slower is growing the start-up company. Therefore, the author found it important to define whether the new company may have a profit in the existing period of development of the state, economy and national economy, and how high the profit can be within 3-5 years. In that context, the question was asked: "How high in your opinion may be the profit of the new 
company within $3-5$ years?"

The opinions of the entrepreneurs in this regard were different. There were some specific opinions and some uncertain thoughts.

There were some respondents who had no idea about this issue, they comprised $10.3 \%$ of the respondents-all from the groups of "nascent entrepreneurs" and "potential entrepreneurs" groups (10 and 6 accordingly).

Mostly, the new company's opportunities to earn a profit within 3-5 years were affected by the industry of the company and its type of business - such answers were given by $25 \%$ of the respondents from the groups of "potential entrepreneurs", "nascent entrepreneurs" and "not involved in entrepreneurship" (12, 16, and 11 accordingly).

All other respondents answered according to their experience in business. The answers were starting from: not possible to earn anything; good, if during these 3-5 years the company can pay credit.

$25 \%$ of the respondents told that the company can make profit; all of them probably had a positive experience-from the groups of "owner of the start-up company", "owners of the mature companies" and "not involved in entrepreneurship" (11, 12 and 16 answers accordingly).

During the study, the author was interested in exploring the problems of the entrepreneurs in the business process, for that reason the question was asked in order to identify the main obstacles.
By responding to the question "Which in your opinion are the main obstacles that are complicating the work of the Latvian entrepreneurs?" each of the respondents had the opportunity to express his opinion in a free form, mentioning a number of obstacles that complicate the business of Latvian entrepreneurs in his opinion, on the basis of his experience.

The grouped obstacles that are complicating the business of the Latvian entrepreneurs are presented in Table 1 by the degree of their importance.

The respondents mostly mentioned taxes as the main obstacles to Latvian entrepreneurs - tax burden (large, huge) taxes, tax legislation (tax policy), tax system which is difficult to be understood, the lack of government support. In total, $53.8 \%$ of all respondents mentioned the tax issues as the major obstacles as well as the lack of government support, the attitude of Saeima deputies to this issue.

Other reasons that complicate the operation of Latvian entrepreneurs were listed less. These obstacles included: low purchasing power of the consumers, the EU, the economic situation in the country, politics, lack of imagination of the entrepreneurs, lack of government support, way of thinking and lack of knowledge of the entrepreneurs.

In the course of the survey, another important obstacle was unexpectedly found: bureaucracy and corruption, which were mentioned by the respondents in $14.1 \%$ of cases. According to entrepreneurs, these issues were not mentioned as important, but major

Table 1 Obstacles that are complicating the business of the Latvian entrepreneurs.

\begin{tabular}{lll}
\hline No. & Name of the obstacle & $\%$ \\
\hline 1. & Taxes, tax rates & 10.9 \\
2. & Tax legislation & 12.8 \\
3. & Tax policy, system & 16.0 \\
4. & The lack of government support also in tax issues & 14.1 \\
5. & Economic situation & 9.6 \\
6. & Lack of knowledge & 7.7 \\
7. & Limited financial resources & 7.7 \\
8. & Bureaucracy, corruption & 14.1 \\
9. & EU & 1.3 \\
10. & Consumer insolvency & 5.8 \\
\hline
\end{tabular}


Table 2 Summarization of the responses to the answer: "What would encourage Latvian entrepreneurs to successfully launch and develop a new business in your opinion?"

\begin{tabular}{lll}
\hline No. & Answers of the respondents & $\%$ \\
\hline 1. & Assistance from the state, public institutions in the field of taxation & 45.5 \\
2. & Exemption from large taxes & 32.1 \\
3. & The need for a "Mentor" & 2.2 \\
4. & Reduction of bureaucracy & 6.8 \\
5. & Resources & 2.2 \\
6. & Moral freedom & 6.8 \\
7. & Trainings for entrepreneurs & 2.2 \\
8. & Cooperation opportunities with foreign countries & 2.2 \\
& TOTAL & 100 \\
\hline
\end{tabular}

problems, despite the fact that there is an active fight against this phenomena at the national level.

Limited financial resources of the company, lack of knowledge of the entrepreneurs and the consumer insolvency were mentioned fewer times as the obstacles to entrepreneurship in comparison to the tax issue.

According to the author's conclusion, the lack of financial resources of the company and the consumer insolvency are directly dependent on the economic situation in the country, and they can be regarded as strong influencing external factors which cannot be affected or otherwise changed by the company. If to take the so-called "fat years" as an example, this problem was not topical for entrepreneurs at that time [8]. Therefore, it can be concluded that the Latvian entrepreneurs still feel the impact of economic crisis, and "blame" the existing state bureaucracy, tax policy and the government's failure to support the entrepreneurs, as they would like.

Notwithstanding the fact that according to the country's leading economists and politicians, the economic crisis in Latvia came to an end long before, the author was interested in the opinions of the entrepreneurs on the key business risks.

The following question has been asked: "Which are the main risks in your opinion, such as insolvency or potential bankruptcy, for Latvian entrepreneurs?"

By summarizing the results of the survey, it was concluded that $47.4 \%$ of respondents mentioned the risk of insolvency as the main risk for Latvian entrepreneurs, $14.7 \%$ of respondents noted bankruptcy as the main risk to the Latvian entrepreneurs, while $35.3 \%$ of respondents described other major risks for Latvian entrepreneurs in their opinion.

The last issue regarded the author's interest on the issue, which would encourage the entrepreneurs to successfully launch and develop a new business. Therefore the following question was asked: "What would encourage Latvian entrepreneurs to successfully launch and develop a new business in your opinion?" By answering this question, the respondents were free to choose the style of the answer and could provide several major versions.

So, on the basis of the responses of the entrepreneurs, the measures that would encourage Latvian entrepreneurs to start and develop new businesses are the assistance from the state and public institutions in the field of taxation and exemption from large taxes $-45.5 \%$ and $32.1 \%$ accordingly.

The survey results are summarized in Table 2 with 8 positions.

The least attention was paid to the aspects, which are marked in Tables 2 of 3, up to the 8th answer.

Any entrepreneur who participated in this survey hopes or dreams of the more liberal tax policy in the country, of the greater government support for entrepreneurship, of the simpler initiation of the enterprise and tax payment procedure at the national level. They hope also for the improving economic situation and the return of the "fat years" to Latvia. 


\section{Conclusions}

On the basis of the above mentioned survey results it can be concluded that the tax issue is very important, according to some responses even extremely important, both for the future and already experienced entrepreneurs. According to the author's conclusion, the too heavy tax burden really complicates not only the operation of new companies, but also the development of entrepreneurship in general.

By analyzing the survey responses, the author arrived to a compelling view that the existing tax policy does not take into account the impact of the economic crisis on the entrepreneurship, and the complex of measures is not actually focused on priming of economy, high financial results and do not take into account the interests of the taxpayers.

Taking into account that the tax policy has the significant role in the promotion and improvement of competitiveness, according to the author's recommendation, it is necessary to review the existing tax policy to the benefit of entrepreneurship.

\section{References}

[1] Latvian Saeima. 1995. "Law "On Taxes and Fees"." Latvijas Vēstnesis 26 (February): 1-6.
[2] Latvian Cabinet of Ministers. 2001. "Pre-accession Economic Programme. Specified in accordance with the Paragraph 21 of the Article 23 of the protocol resolution of the meeting of Cabinet of Ministers from 15 May 2001." Latvijas Vēstnesis 95 (June): 1-8.

[3] Latvian Cabinet of Ministers. 2002. "Ordinance of the Cabinet of Ministers No. 428 On the Pre-accession Economic Programme." Latvijas Vēstnesis 117 (August): 3-5.

[4] E. Sipola. 2014. "Entrepreneurship Survey." Presented at the 56th International Scientific Conference of Daugavpils University, Daugavpils, Latvia.

[5] Latvian Ministry of Finance. 2010. "Tax and Fee System Development Guidelines for 2011-2015." Latvian Ministry of Finance. Accessed June 14, 2010. http://www.knl.lv/data/File/Nodoklu\%20pamatnostadnes \%2001\%2003\%202010.pdf (in Latvian).

[6] Latvian Ministry of Finance. 2011. "Tax Policy Strategy for 2011-2014." Latvian Ministry of Finance. Accessed September 7, 2011. http://www.fm.gov.lv/lv/sadalas/ nodoklu_politika/nodoklu_politikas_strategija_2011_201 4_gadam (in Latvian).

[7] Latvian Ministry of Finance. 2012. "On the EC Recommendations for the Convergence Programme." Latvian Ministry of Finance. Accessed Mai 30, 2012. http://212.70.165.10/news/fm-konceptuali-atbalsta-ek-rek omendacijas-par-latvijas-konvergences-programmu (in Latvian).

[8] Ābika L. 2008. "Nodokḷi un to ietekme uz ekonomikas attīstību Latvijā." Latvijas Universitātes raksti Ekonomika VII: 373. 